\title{
Bcadrunkw
}






\section{с барельефов}

\section{Bячеслав Шиаковекий}

кандидат исторических наук

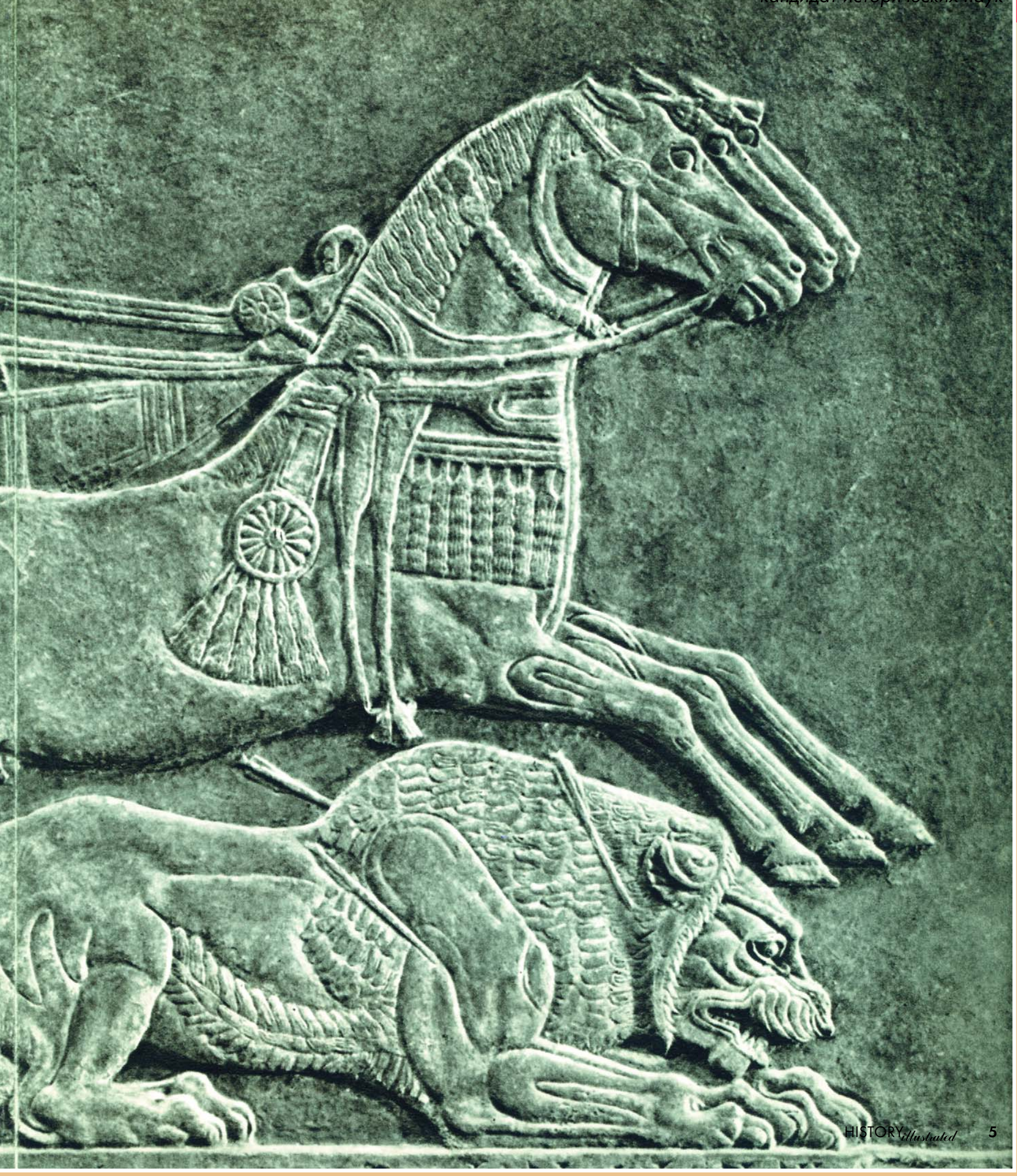




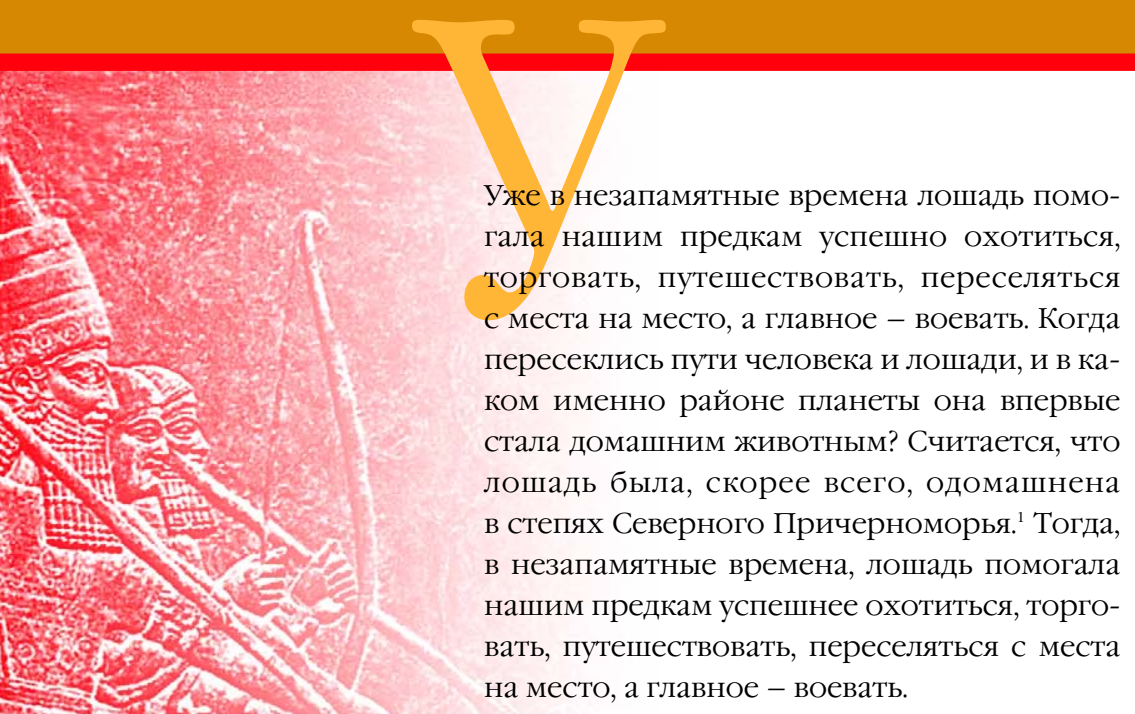

часть веса колесницы вместе с дышлом принимали на себя и запряженные в нее лошади. Обычно в такой колеснице, запряженной двумя или тремя лошадьми, располагался возница и один или два лучника.

Впрочем, собственно верховая езда была известна и во времена боевых колесниц, и какое-то время их развитие шло параллельно, о чем свидетельствует древнеиндийская поэма «Махабхарата», где всадники упоминаются вместе с колесницами.

Роль лошади ${ }^{2}$ в жизни человека постепенно возрастала, что хорошо подтвержда-

\section{Роль лошади в жизни человека постепенно возрас- тала, что хорошо подтверждается многочисленными археологическими находками конской сбруи, кото- рую клали вместе с умершими наряду с оружием, украшениями и другими «необходимыми» вещами, хотя, конечно, очень многое в древних погребениях от времени не сохранилось.}

Уже на рельефах древних шумеров, живших в Месопотамии в III тысячелетии до н. э., встречаются изображения четырехколесных колесниц, в которых, по-видимому, запрягали ослов и мулов. Гораздо удобнее и быстроходнее оказались боевые повозки хеттов, ассирийцев и египтян - широко распространившиеся на территории Передней Азии и Северной Африки в середине II тысячелетия до н. э. Колесницы этих народов были уже одноосными, причем ось на них крепилась позади повозки, так что ется многочисленными археологическими находками конской сбруи, которую клали вместе с умершими наряду с оружием, украшениями и другими «необходимыми» вещами, хотя, конечно, очень многое в древних погребениях от времени не сохранилось. Тем не менее, на основании имеющихся в распоряжении историков находок, а также дошедших до нашего времени изображений, можно считать, что вначале люди ездили на неоседланных лошадях. Потом на спину лошади для удобства всадника стали

Ассирийский всадник. Фрагмент рельефа из Ниневии. VIIв. до н.э. $\Rightarrow$ Лувр, Париж.

Однако с августа 2011 года, по сообщениям әлектронных средств массовой информации, на первенство в деле одомашнивания лошади стала претендовать археологическая культура Аль-Магар, недавно обнаруженная в Саудовской Аравии. Останки лошадей, наконечники стрел, каменные приспособления и инструменты для изготовления нитей и тканей, ступы и пестики для размалывания зерен, обнаруженные в рамках этой культуры, ярко свидетельствует о том, ито жизнь древних была тесно связана с лошадыми. Радиоуглеродный анализ указанных находок показал, что им никак не меньие 9000 лет.

${ }^{2}$ Слово «лошадь» восточные славяне переняли у тюркских народов, на языке которых оно звучало как «алоша». Произошло это во время перекочевок тюркских племен в южно-русских степях, когда они очень близко сталкивались со славянами Приднепровъя. Слова «конъ", «кобыла» встречаютося в языках многих славянских народов, а их корни восходят к индоевропейскому праязыку, недаром так похожи слова «кабаль", «иеваль", от которых в Испании и во Франции произоили наименования цельх сословий конных воинов-дворян: кабальеро и шевалье, да и сам термин ккавалерия» тоже. 


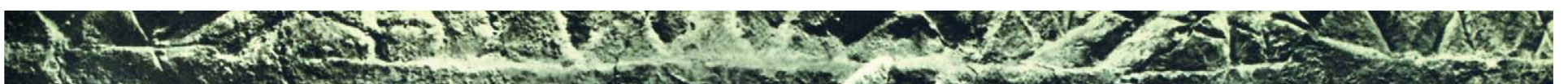

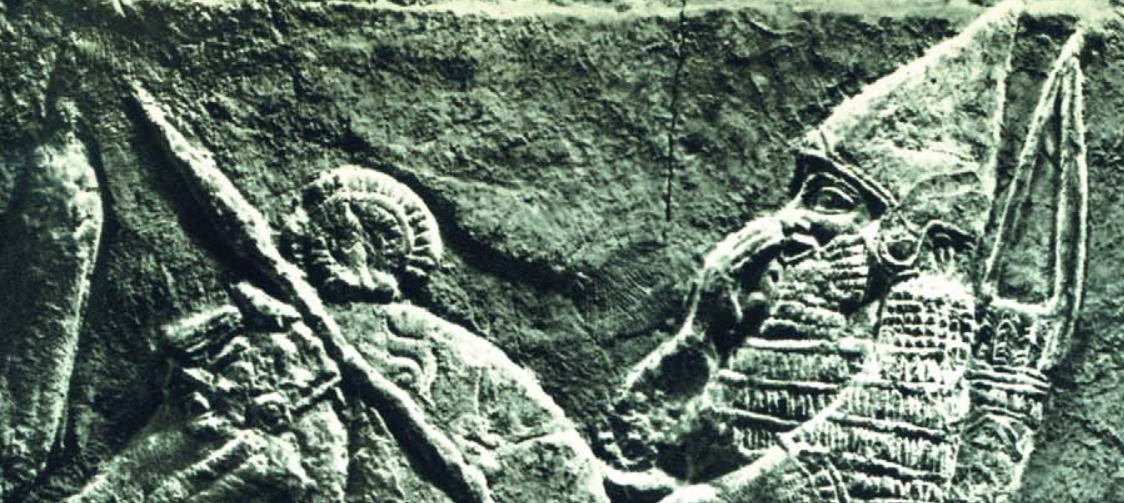

.

sute

12

T.t 3
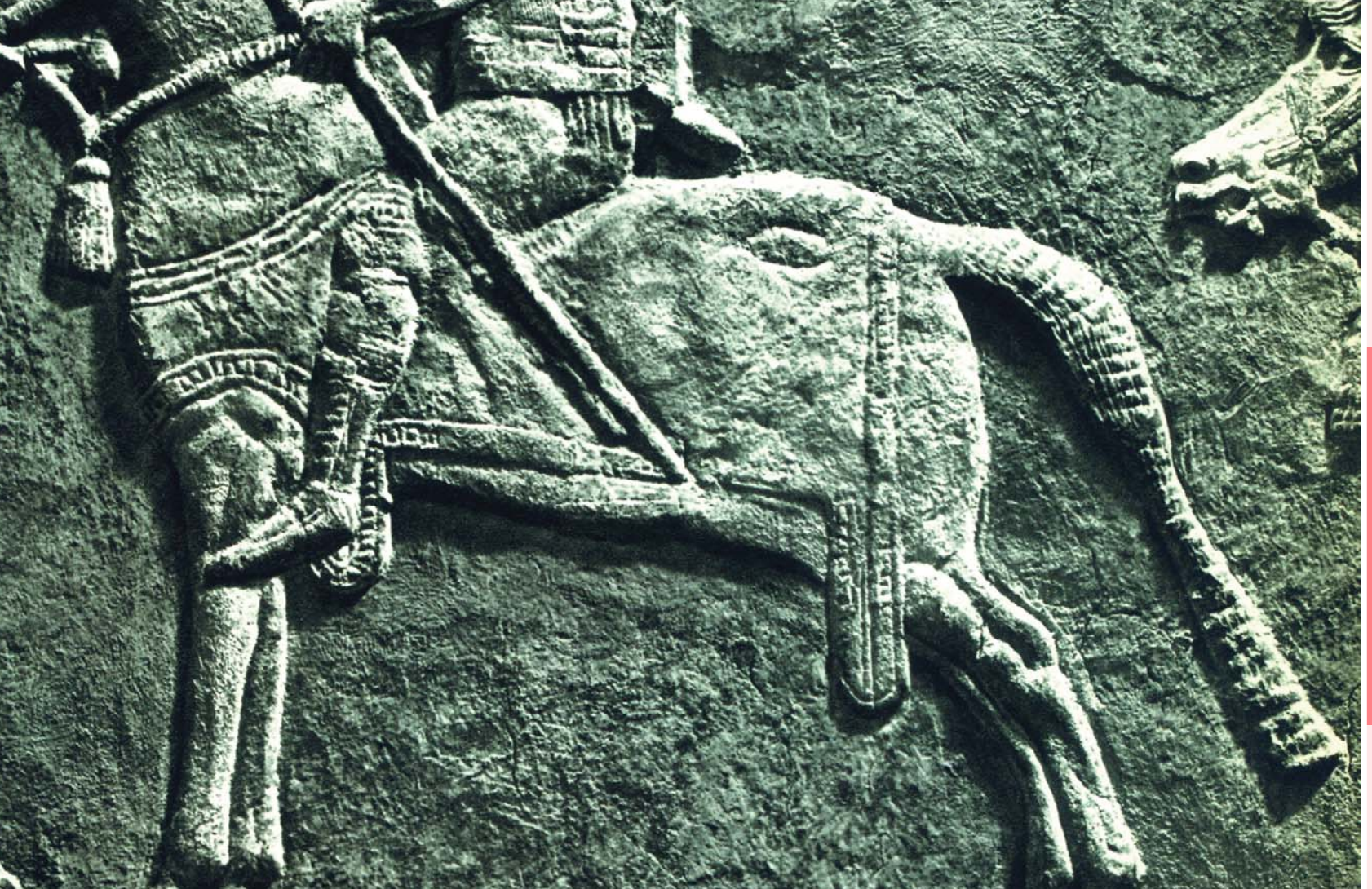

1.

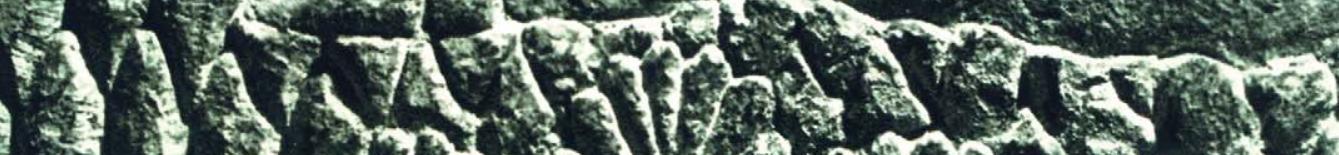

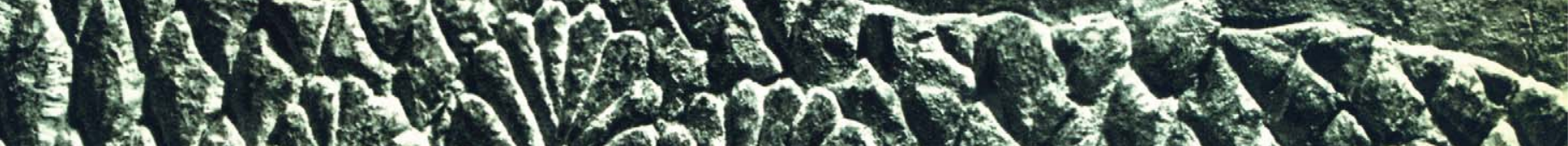



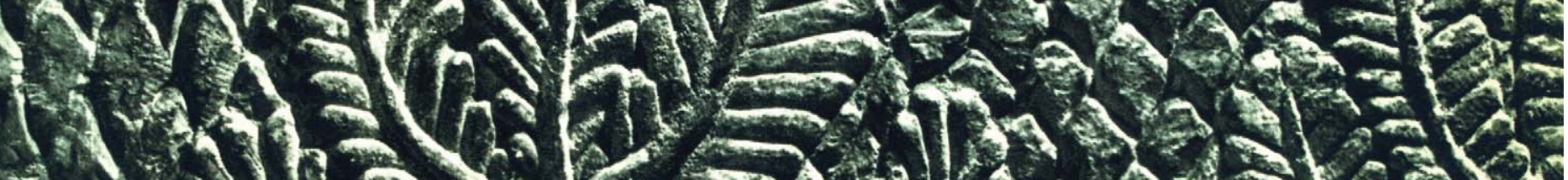

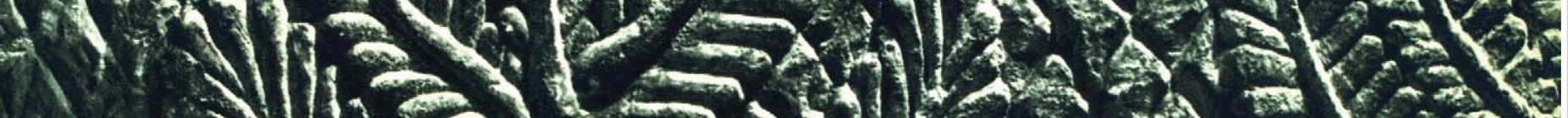

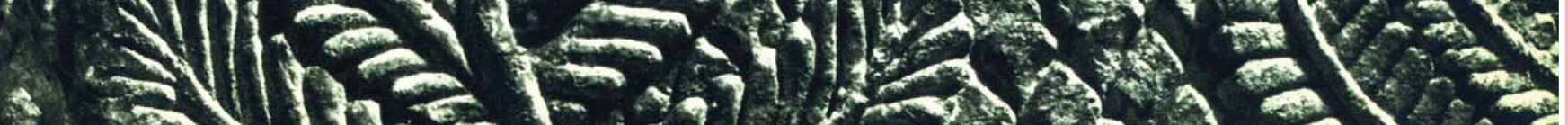

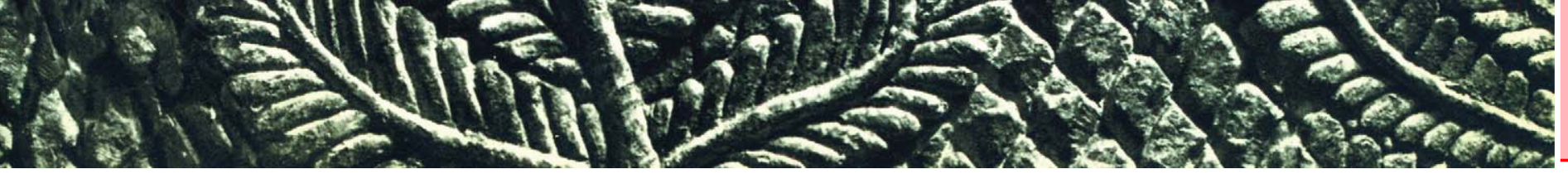




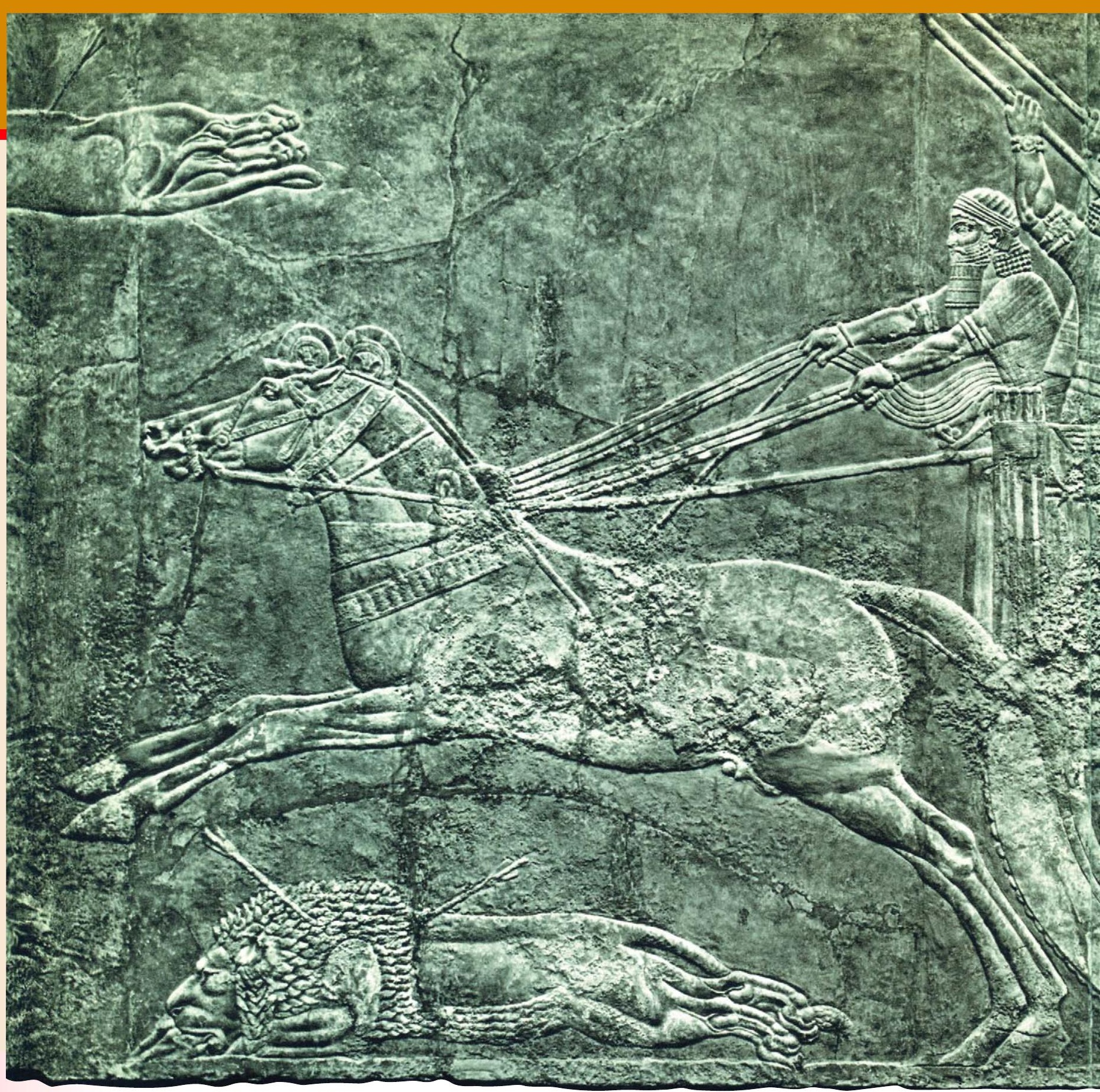

подкладывать подстилку из шкуры либо попону, но так как подобное седло не могло не сползать, его начали стараться зафиксировать, в результате чего и появилась подпруга. Точно так же вначале употреблялись мягкие удила, о чем свидетельствуют даже данные этнографии. Например, подобные мягкие удила часто делали крестьяне глухих деревень царской России. Для этого на куске ремня или веревки обычно завязывали узлы. Расстояние между средними узлами делалось на 5-7 см больше ширины челюсти лошади. Чтобы уздечка не «продергивалась», в эти узды вставляли по одной палочке длиной около 8-10 см. с вырезами в середине. Затем «удила» обильно смазывались дегтем или жиром. После взнуздывания концы ремня соединялись и заводились за затылок лошади, а между средними и крайними узлами крепился повод. Наверняка использовался и тип узды, принятый у индейцев Северной Америки в виде простой ременной петли, на- детой на нижнюю челюсть лошади. Но этот недостаток, скорее всего, был очевиден уже тогда: лошадь могла изжевать, а то и просто перекусить такие удила, вот почему их начали делать из металла. А чтобы грызло всегда находилось во рту лошади, стали применять псалии, фиксировавшие удила. В Древнем мире всадник являлся серьезным противником для пехотинцев, особенно если ездить на лошади он приучался с раннего детства. Собственно говоря, именно так и родилась конница. 


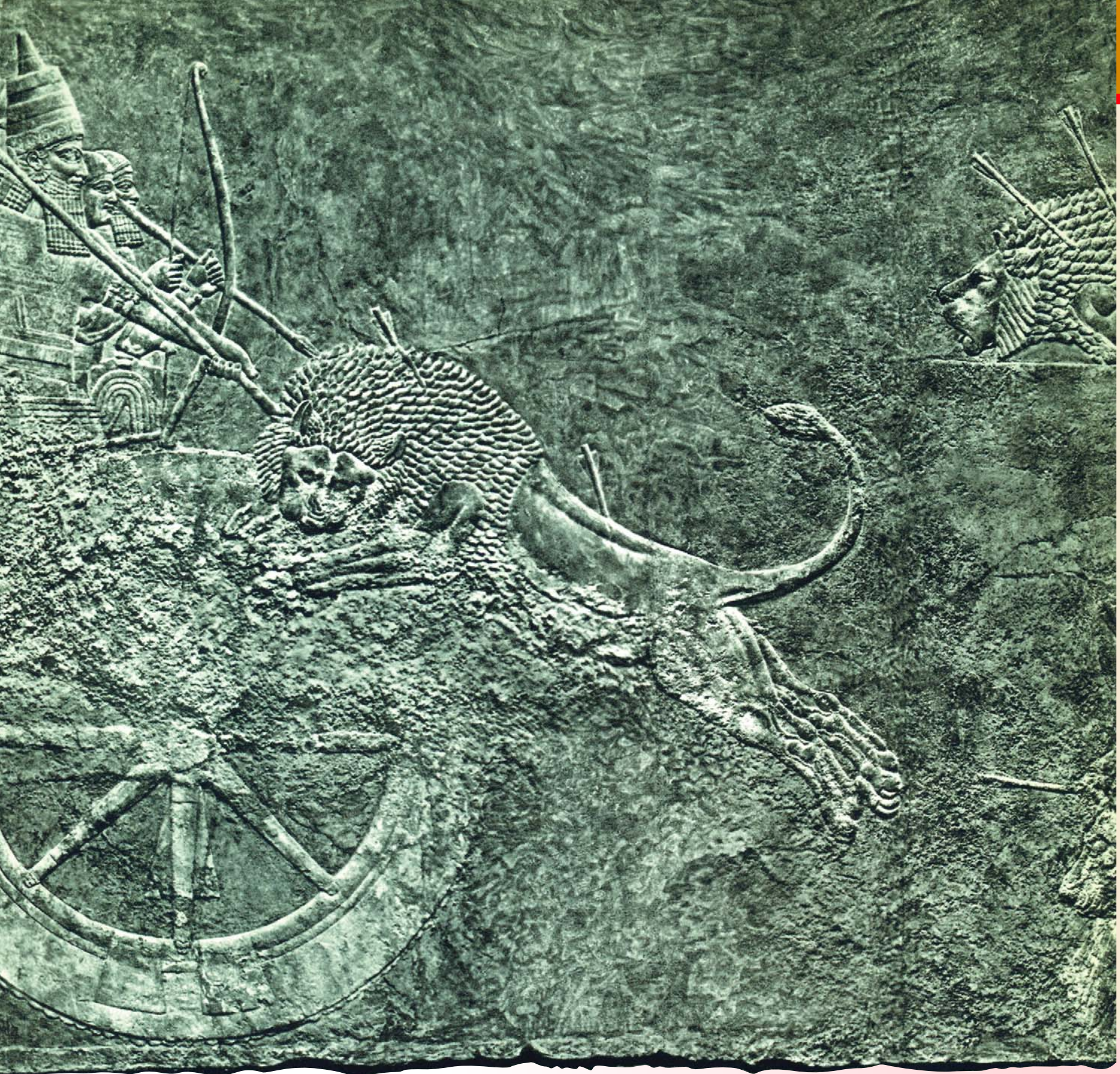

Изображения первых воиноввсадников дошли до нас благодаря раскопкам древних городов Ассирии - Ниневии, Хорсабада и Нимруда, где среди развалин дворцов ассирийских царей были найдены хорошо сохранившиеся рельефы, изображавшие сцены из жизни ассирийской державы. На их основании можно судить, что искусство конного боя в Ассирии в своем развитии прошло три этапа.

Так, рельефы эпохи правления царя Ашшурнасирпала II (883-859 гг.
Охота на львов царя Ашшурбанипала. Фрагмент рельефа из Ниневии. VII в. до н.э. Лувр, Париж.

Изображения первых воинов-всадников дошли до нас благодаря раскопкам древних городов Ассирии, где среди развалин дворцов были найдены хорошо сохранившиеся рельефы, изображавшие сцены из жизни ассирийской державы. 
Охота на львов царя Ашшурбанипала. Фрагмент рельефа из Ниневии. VII в. до н.э. Лувр, Париж. до н. э.) и Салманасара III (858 - 824 гг. до н.э.) показывают нам легковооруженных конных лучников, некоторых - с двумя лошадьми. Видимо, лошади того времени были недостаточно сильны и выносливы, и воинам требовалось их часто менять. При этом всадники действуют в паре: один - щитоносец - управляет сразу двумя лошадьми, тогда как другой стреляет из лука. Видимо, функция ассирийских всадников тогда была чисто вспомогательной и сводилась к роли ездящих стрелков из лука. По сути дела, это были «колесничие без колеснищ".

Однако уже при царе Тиглатпалаcape III (745-727 гг. до н. э.) в ассирийском войске было три вида всадников: легковооруженные воины с луками и дротиками, скорее всего принадлежавшие к соседним с Ассирией кочевым племенам и выступавшие в роли союзников или наемников; конные лучники в защитных доспехах из металлических пластинок; тяжеловооруженные всадники с копьями и щитами, использовавшиеся для атаки пехоты противника. Боевые колесницы дополняли конницу, не более.

Конные лучники ассирийцев были хорошими наездниками, однако их действия очень затрудняло отсутствие седла и стремян. Всадникам приходилось удерживаться на лошади, закинув ноги высоко на круп, либо - свесив их вниз, как это показано на ассирийских рельефах. Повод поэтому был довольно тугим и коротким. Удила были устроены так, чтобы их было трудно выдернуть изо рта лошади. Такие удила, безусловно, травмировали губы лошади, но с этим мирились, так как без строгой узды ездить без седла и стремян было весьма затруднительно. Видимо, ассирийцы управляли лошадьми не столько уздой, сколько шенкелями (сдавливая бока ногами), и подавая им команды голосом.

Глядя на ассирийские рельефы, можно представить одежду и вооружение всадника. Кафтан всадника напоминает английский редингот

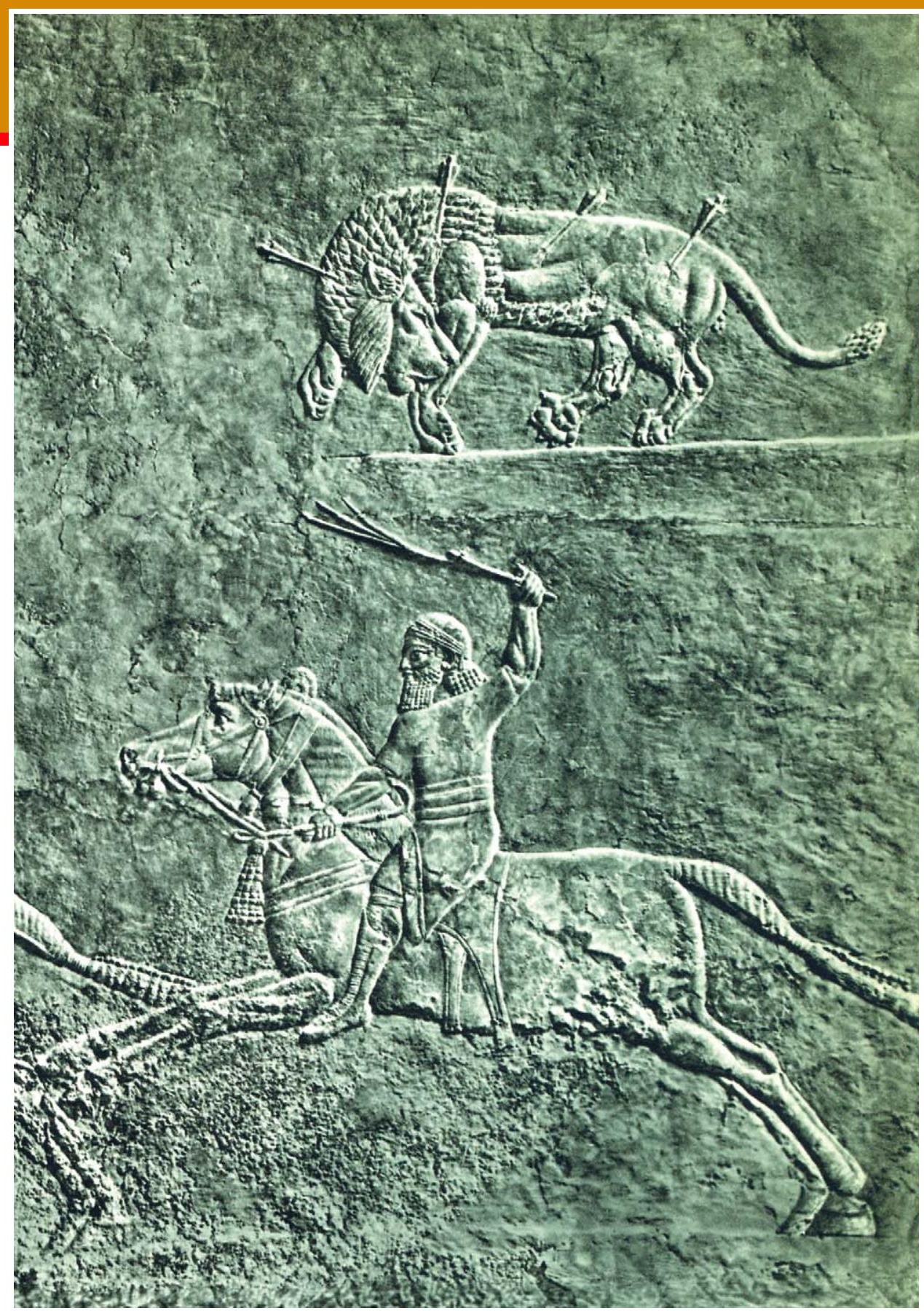

и имеет разрезы спереди и сзади. Пластинки панцирного корсета на нем связывались между собой при помощи кожаных ремешков, что

облегчало подгонку доспеха по фигуре воина. Сбрую коней ассирийцы ради красоты покрывали бронзовыми бляшками.

\section{Конные лучники были хорошими наездни-} ками, однако их действия очень затрудняло отсутствие седла и стремян. Всадникам приходилось удерживаться на лошади, закинув ноги высоко на круп, либо - свесив их вниз, как это показано на ассирийских рельефах. 